\title{
Summer dynamics of Alexandrium ostenfeldii (Dinophyceae) and spirolide toxins in Cork Harbour, Ireland
}

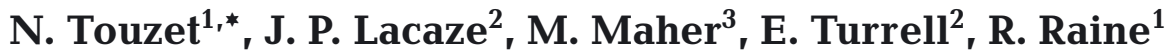 \\ ${ }^{1}$ The Martin Ryan Institute, School of Natural Sciences, National University of Ireland, Galway, Ireland \\ ${ }^{2}$ Marine Scotland, Marine Laboratory, 375 Victoria Road, Aberdeen AB11 9DB, UK \\ ${ }^{3}$ Molecular Diagnostics Research Group, National Centre for Biomedical Engineering Science, National University of \\ Ireland, Galway, Ireland
}

\begin{abstract}
Proliferations of toxic Alexandrium spp. have adversely affected the shellfish aquaculture industry worldwide. A. ostenfeldii can produce several biotoxins, including the recently characterised fast-acting toxins spirolides (SPX). A dual labelling fluorescent in situ hybridisation (FISH) assay was developed for discriminating simultaneously between the closely related taxa A. ostenfeldii and A. peruvianum. Surveys were undertaken throughout the summers of 2006, 2007 and 2008 in Cork Harbour, Ireland, where a mixed community of Alexandrium spp. develops annually. A. peruvianum was not detected but the presence of $A$. ostenfeldii was confirmed by FISH and mor-

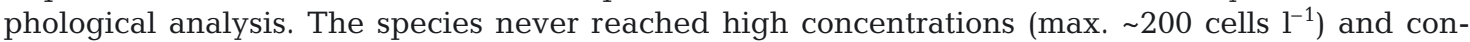
tributed on average to only $0.4 \%$ of the Alexandrium community, usually dominated by A. minutum and A. tamarense (Group III). Although cell concentrations were several orders of magnitude lower, the dynamics of $A$. ostenfeldii were similar to those of other Alexandrium spp. during the 3 consecutive summers, suggesting a common response to environmental forcing. Analytical chemistry performed on extracts from passive solid-phase adsorption samplers identified lipophilic toxins dominated by okadaic acid, but also 13-desmethyl SPX C and 20-methyl SPX G, with dynamics generally congruent with those of $A$. ostenfeldii. The passive samplers enabled the quantification of background toxin levels at very low A. ostenfeldii concentrations, showing potential for forecasting of toxic events. The ability to quantify toxic A. ostenfeldii cells within high density microalgal populations of morphologically similar species makes the dual FISH assay valuable for phytoplankton monitoring programs and future biogeographical and population dynamics studies.
\end{abstract}

KEY WORDS: Harmful algal bloom - HAB · Alexandrium - Solid-phase adsorption toxin tracking • SPATT · Spirolides · Fluorescent in situ hybridisation · FISH · Cork Harbour

Resale or republication not permitted without written consent of the publisher

\section{INTRODUCTION}

Noxious microalgae constitute a serious threat to human health because of the potential accumulation of potent biotoxins in seafood products (GEOHAB 2001). The requirement to produce safe and quality seafood, together with the apparent increase in the frequency of harmful algal bloom (HAB) occurrences and toxic events in coastal environments, has led to the implementation of phytoplankton and biotoxin monitoring programmes in many countries (Andersen et al. 2003). Substantial efforts have been directed towards the enhancement of bloom-prediction capacities using bio-physical models of bloom development and towards the early detection of biotoxins in the water (Mackenzie et al. 2004, McGillicuddy et al. 2005).

The dinoflagellate genus Alexandrium comprises $~ 30$ species, with several having the capacity to synthesise potent biotoxins (Anderson 1998). Some species are cosmopolitan whereas others have distributions restricted to 
specific geographic areas (Balech 1995). Members of the A. tamarense species complex and the A. minutum clade have frequently been involved in shellfish contamination with levels of neurotoxins unsafe for human consumption (FAO 2004). The corresponding human intoxication syndrome, known as paralytic shellfish poisoning (PSP), is caused by structural derivatives of the alkaloid compound saxitoxin. Spirolides (SPXs) are lipophilic marine biotoxins that were discovered more recently. These macrocyclic imines were first characterised from A. ostenfeldii cells following monitoring of shellfish in Canada (Cembella et al. 2000). SPXs are potent fastacting toxins that interact with muscarinic receptors in nerve cells and cause acute neurotoxic activity in mice (40 and $1000 \mu \mathrm{g} \mathrm{kg}^{-1}$ for intra-peritoneal injection and oral administration, respectively) (Richard et al. 2001). SPX-producing strains of $A$. ostenfeldii and A. peruvianum have been isolated from various coastal areas around the world and have shown variations in SPX and/or PSP toxin composition, making toxin profiles promising as global population biomarkers (Mackenzie et al. 1996, Cembella et al. 1998, 2000, 2001, John et al. 2003, Percy et al. 2004, Lim et al. 2005, Touzet et al. 2008a, Kremp et al. 2009).

Shellfish safety has improved following the implementation of phytoplankton monitoring and biotoxin screening programmes. The recent introduction of a methodology based on passive sampling has proved beneficial for microalgal toxin monitoring (Mackenzie et al. 2004). The use of polymeric resins entrapped in mesh containers and deployed in the water column has allowed the simultaneous detection of multiple biotoxins (Mackenzie et al. 2004, Turrell et al. 2007, Fux et al. 2009, Rundberget et al. 2009). The problem of interfering compounds co-extracted from biological matrices, such as shellfish tissues, can be greatly reduced by using these solid-phase adsorption toxin tracking (SPATT) devices (Mackenzie et al. 2004).

A major issue in phytoplankton monitoring, and of Alexandrium spp. in particular, is that toxic populations often constitute low proportions of phytoplankton assemblages and also co-occur with morphologically similar species. Accurate identification is very tedious and often cannot be reliably ascertained by light microscopy. Molecular detection of HABs has increased and a variety of formats has been used, including real-time $\mathrm{PCR}$, fluorescent in situ hybridisation (FISH), sandwich hybridisation (SH), quartz balance and micro-arrays (Kim et al. 2005, Lazerges et al. 2006, Diercks et al. 2008, Gescher et al. 2008, Touzet et al. 2009). FISH has proved a popular method for detecting and quantifying Alexandrium spp. in discrete seawater samples because of the simplicity of protocols and the low costs involved (Hosoi-Tanabe \& Sako 2004, Gribble et al. 2005, John et al. 2005). Although sample throughput can be limited to a dozen daily analyses, the method enables the simultaneous detection and quantification of co-occurring armoured dinoflagellates when using the cellulose-staining dye calcofluor (Anderson et al. 2005, Touzet et al. 2008b).

A substantial body of literature is available for studies carried out on members of the Alexandrium tamarense and A. minutum species complexes. Other potentially toxic species of the genus have been the centre of increased focus in recent years, in particular the closely related spirolide-producing taxa $A$. ostenfeldii and A. peruvianum (John et al. 2003, Maclean et al. 2003, Gribble et al. 2005, Lim et al. 2005, Touzet et al. 2008a, Kremp et al. 2009). Pending questions relate to the ecophysiology of toxin production and the metabolic conversion by filter-feeding shellfish, the separation of the 2 taxa as distinct species or regional varieties/ribotypes and the extent of their respective global distribution. For biogeographical purposes in particular, the development of molecular tools for accurate discrimination and identification of the taxa has become a necessity.

Alexandrium is commonly found during the summer months in coastal areas of Ireland, where at least 6 species have been morphogenetically characterised, including both $A$. ostenfeldii and $A$. peruvianum from isolated cultures (Touzet et al. 2008a). Issues related to recurrent contamination of shellfish with saxitoxins produced by Alexandrium spp. have been limited to Cork Harbour, an estuary located on the south coast of the country. Mixed blooms of A. minutum and A. tamarense occur on a nearly annual basis in the North Channel (Touzet et al. 2008b), a restricted area of the estuary where the presence of minor proportions of A. ostenfeldii, tentatively detected at times by light microscopy, needs to be confirmed. The present study documents the application of a dual FISH assay specifically designed to discriminate between European A. ostenfeldii and A. peruvianum ribotypes. The assay was used in conjunction with other probes to investigate the water column dynamics of $A$. ostenfeldii and other Alexandrium spp. in Cork Harbour during surveys carried out in the summers of 2006, 2007 and 2008. The passive adsorption of spirolides and other lipophilic toxins to resin-filled samplers deployed in the North Channel was also carried out to relate the potential presence of known biotoxins to the levels of suspected causative HAB microorganisms.

\section{MATERIALS AND METHODS}

Culturing of dinoflagellates. Cultures of Alexandrium ostenfeldii and $A$. peruvianum strains derived from resting cysts isolated along the southwest and north coasts of 
Ireland were selected for the design and testing of taxaspecific oligonucleotide probes. Several Alexandrium spp. and other dinoflagellate strains from Irish coastal waters were used for cross-reactivity tests (as in Touzet et al. 2009). All cultures were maintained in an illuminated culture chamber under a $14 \mathrm{~h}$ light:10 h dark cycle (photon flux density of $100 \mu \mathrm{mol} \mathrm{m} \mathrm{m}^{-2} \mathrm{~s}^{-1}$ ) at $15^{\circ} \mathrm{C}$ in $\mathrm{f} / 2$ medium minus silicate (Guillard 1975).

DNA extraction, LSU and SSU rDNA PCR and sequencing. Extraction of genomic DNA was carried out using a QIAGEN DNeasy ${ }^{\circledR}$ Plant Mini Kit on cell pellets obtained after centrifugation $(4000 \times g, 10 \mathrm{~min})$ of culture suspensions. Amplifications of the D1-D2 domain of the large subunit (LSU) and small subunit (SSU) rDNA were performed in $50 \mu$ l reaction using the primer sets from Lenaers et al. (1989) and Sogin (1990), respectively. Concentrations of chemicals and thermocycling conditions were those used in Touzet et al. (2008a). The amplified PCR products were visualised through UV illumination on $1 \%$ agarose-1X TAE buffer gel containing ethidium bromide (1 $\mu \mathrm{g}$ $\mathrm{ml}^{-1}$ ) and were purified using the QIAquick ${ }^{\circledR}$ PCR Purification Kit. Sequencing was performed by MWG Biotech (Germany).

Sequence alignment and probe design. The rDNA sequences of Irish Alexandrium ostenfeldii and A. peruvianum strains were compiled with those of other Alexandrium spp. imported from GenBank and aligned using the Pairwise Alignment function of Genedoc. The imported Alexandrium spp. sequences pertaining to the LSU rDNA had the following accession numbers: FJ011440, FJ011438, AJ535363, AJ535357, AJ535358, AB088248, AF318264, AJ535372, AF318229, AF318230, AY566183 and AJ535370. The accession numbers of the imported SSU rDNA sequences were: AJ535382, AJ535381, AJ535381, U27500, AJ535383, AJ535378, U27499, AY883006, AB088302, AY641564, AJ535385, U09048, AY883004, AY421777 and AB088315.

At least one specific probe targeting the LSU rDNA is available for Alexandrium ostenfeldii (John et al. 2003). A new set of 2 probes with matching hybridisation properties under FISH conditions was developed in the present study to enable the dual labelling of
A. ostenfeldii and A. peruvianum. Oligonucleotide probes were designed after identification of sites displaying suitable degrees of specificity in the sequence alignments. The probes Ost-I and Ost/Peru-J (Table 1) were screened using the Basic Local Alignment Search Tool (BLAST) (Altschul et al. 1990) to examine their specificity against a wide range of organisms in databases. Probes were obtained from MWG Biotech and synthesised with the $5^{\prime}$ end labelled with fluorescein isothiocyanate (FITC) and CY.3 for Ost-I and Ost/ Peru-J, respectively. Upon receipt, concentrated probe stocks were diluted in double-distilled water (final concentration $250 \mathrm{ng}^{-1} \mathrm{l}^{-1}$ ), separated in $100 \mu \mathrm{l}$ aliquots and stored at $-24^{\circ} \mathrm{C}$ as working solutions.

Fixation and processing of culture samples. Alexandrium spp. and other dinoflagellate cultured cells were harvested and fixed for $1 \mathrm{~h}$ in formalin (1\% final concentration v/v). After centrifugation $(4000 \times g, 10 \mathrm{~min})$, supernatants were removed by aspiration and cells were suspended in $1 \mathrm{ml}$ of $100 \%$ ice-cold methanol to remove pigments and stabilise nucleic acids. Samples were stored at $-24^{\circ} \mathrm{C}$ until analysis.

Seawater sampling. Field samples used in this study were collected during the summers of 2006, 2007 and 2008 in Cork Harbour, an inlet situated on the south Irish coast at $51^{\circ} 50^{\prime} \mathrm{N}$ and $8^{\circ} 16^{\prime} \mathrm{W}$ (Fig. 1). The study site comprised stations in the North Channel, the main harbour and Lough Mahon. Surface seawater samples $(50 \mathrm{ml})$ for microscopy analysis were collected and immediately fixed with buffered formalin (1\% final concentration v/v). Subsurface samples were also obtained at varying depths for each station in 2006 and 2007, based on the interpretation of in situ chlorophyll fluorescence measurements carried out with a fluorometer (SeaTech). Additional samples were collected for detection and enumeration of Alexandrium spp. by FISH. To this end, 21 seawater volumes for each station and depth sampled were passed through a $150 \mu \mathrm{m}$ mesh sieve and concentrated onto a $5 \mu \mathrm{m}$ mesh filter (47 $\mathrm{mm}$ diameter). The retained planktonic material was then backwashed into $50 \mathrm{ml}$ polypropylene tubes with $0.22 \mu \mathrm{m}$ filtered seawater and fixed with formalin ( $1 \%$ final concentration v/v). Samples were kept in the dark until further processing on land within $24 \mathrm{~h}$.

Table 1. Taxon-specific oligonucleotide probes targeting sites in the rDNA gene operon of Alexandrium ostenfeldii and A. peruvianum. FITC: fluorescein isothiocyanate

\begin{tabular}{|llll|}
\hline Target taxon & Probe sequence $\left(5^{\prime}-3^{\prime}\right)$ & Target & Fluorochrome $\left(5^{\prime}\right)$ \\
\hline A. ostenfeldii & Ost-I.CAATAGTCAGGTTTTGTTGCA & SSU rDNA & FITC \\
A. ostenfeldii/peruvianum & Ost/Peru-J.TGCAGAAATAGACGCTGACAT & LSU rDNA & CY.3 \\
A. minutum & Min-A.TTATATGGTTGATGTGGGTGC & LSU rDNA & CY.3 \\
A. tamarense (gr.III) & Tam-A.TAGGTTTTGCTGTGGGTGA & LSU rDNA & FITC \\
\hline
\end{tabular}




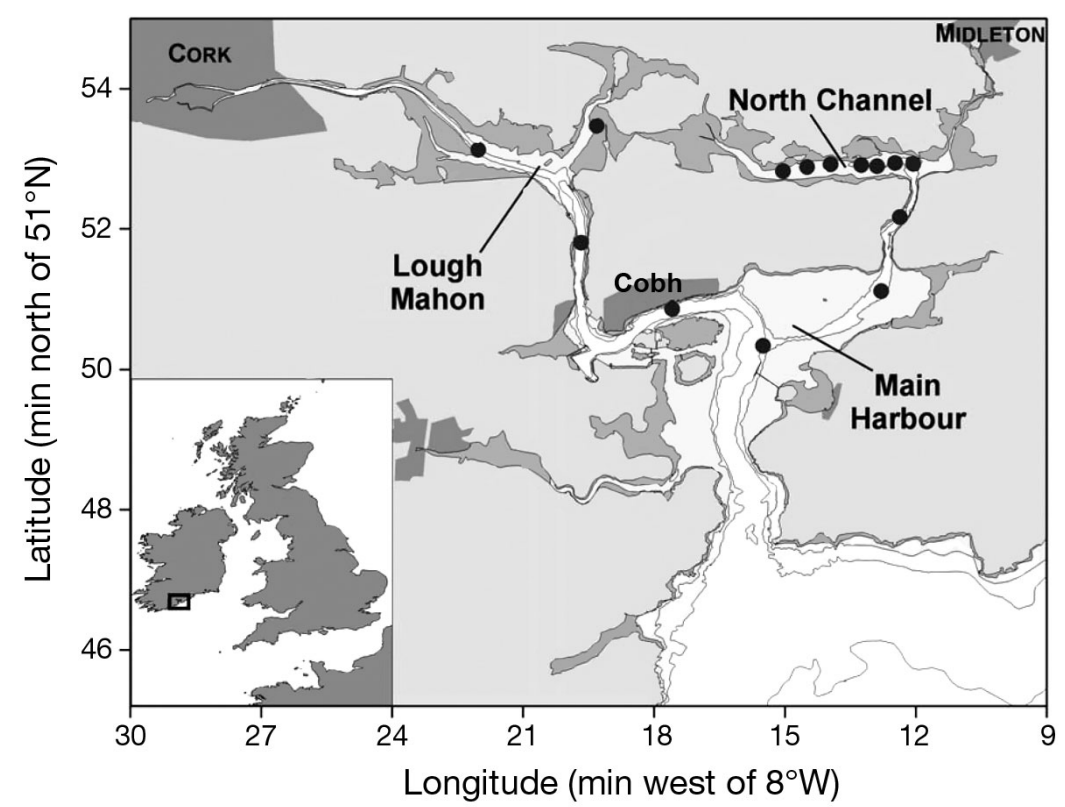

Fig. 1. Cork Harbour, indicating the stations sampled (•) during the summers of 2006, 2007 and 2008. The mid-grey zones highlight areas exposed at low tide

\section{Morphology-based quantification of Alexandrium} spp. Alexandrium spp. quantification in taxonomic samples was performed using an Utermöhl sedimentation chamber (Utermöhl 1958). Armoured dinoflagellates were stained with calcofluor (Fritz \& Triemer 1985) and examined with an inverted microscope (Olympus CKX-41) fitted with adapted epifluorescence optics. Total Alexandrium sp. cell counts were carried out for each sample. In dubious cases, cells were rotated with a dissecting needle to observe the morphological characteristics of the thecal plates (Balech 1995). Highly concentrated samples were diluted prior to examination. Observations were carried out at $\times 200$ and $\times 400$ magnifications.

Whole-cell FISH analysis and epifluorescence microscopy. Samples collected for FISH analysis were immediately centrifuged $(4000 \times g, 5 \mathrm{~min})$ once back on land and the supernatants were carefully discarded by aspiration. Pellets were treated with $15 \mathrm{ml} 100 \%$ ice-cold methanol and stored at $-24^{\circ} \mathrm{C}$ until analysis. Whole-cell FISH for the simultaneous detection of Alexandrium ostenfeldii and A. peruvianum, and A. minutum and A. tamarense (Group III), was carried out using the 2 probe sets Ost-I and Ost/Peru-J, and Min-A and Tam-A, respectively, as described in Touzet et al. (2008b) (Table 1). Briefly, samples filtered on membranes were incubated at room temperature for 2 min with $400 \mu$ l hybridisation buffer (5X SET, $0.1 \%$ IGEPAL). After filtration, $400 \mu$ l hybridisation buffer containing $500 \mathrm{ng}$ of each probe was added onto each filter prior to incubation $\left(55^{\circ} \mathrm{C}, 60 \mathrm{~min}\right)$. After filtration and subsequent washing steps, membranes were mounted between a slide and coverslip with $5 \mu \mathrm{l}$ of a mix of calcofluor $\left(100 \mu \mathrm{g} \mathrm{ml} \mathrm{m}^{-1}\right)$ and DAPI $(3 \mu \mathrm{g}$ $\mathrm{ml}^{-1}$ ) and $10 \mu \mathrm{l}$ of SlowFade ${ }^{\circledR}$ Light Antifade (Molecular Probes).

Membranes were examined with a microscope (Olympus CKX-41) fitted with a U-RFL-T epifluorescence attachment and a $100 \mathrm{~W}$ Mercury lamp. The following filter combinations were used for the detection of the signals: calcofluor and DAPI (355DF25 excitation filter, 400DRLP dichroic mirror and 420 band pass barrier filter), FITC (485DF22 excitation filter, 505DRLP dichroic mirror and 530DF30 barrier filter) and CY.3 (525AF45 excitation filter, 560DRLP dichroic mirror and 595AF60 barrier filter). Membrane examinations were performed at $\times 200$ magnification by scanning the entire filter surface and counting all positive signals. Probe specificity was confirmed for each positive signal by switching on/off the different fluorescent filter sets and briefly inspecting the general organisation of the Alexandrium plate tabulation with calcofluor.

SPATT composition, deployment and extraction. Synthetic adsorbent resin (5 g of SEPABEADS ${ }^{\circledR}$ SP700; Mitsubishi Chemical Cooperation) held within $95 \mu \mathrm{m}$ nylon mesh sachets (50 mm diameter) was suspended at $0.5 \mathrm{~m}$ to a moored line in the North Channel area of Cork Harbour $\left(51^{\circ} 52.94^{\prime} \mathrm{N}, 8^{\circ} 14.45^{\prime} \mathrm{W}\right)$. The sachets were retrieved and new ones were deployed on a weekly basis. However, some variation ensued because of operational constraints such as boat availability or unfavourable wind conditions.

SPATT samplers were returned to the laboratory and stored frozen at $-24^{\circ} \mathrm{C}$ prior to extraction and analysis of toxins. Sachets were defrosted at room temperature for $1 \mathrm{~h}$ and the SP700 resin was fully retrieved into a glass bottle using deionised water $(250 \mathrm{ml})$. After homogenisation with a vortex mixer, the resin beads were poured into a $20 \mu \mathrm{m}$ fritted cartridge $(25 \mathrm{ml})$ and rinsed with distilled water $(100 \mathrm{ml})$. The interstitial water was removed using a low vacuum and $100 \%$ methanol $(10 \mathrm{ml})$ was added to the resin beads. The cartridge content was mixed using a vortex mixer for $1 \mathrm{~min}$ and allowed to soak in the methanol for $30 \mathrm{~min}$ prior to collection of the eluent. The resin was further eluted with $90 \mathrm{ml}$ methanol and the eluents were pooled together. An aliquot $(10 \mathrm{ml})$ was then evaporated to dryness at $45^{\circ} \mathrm{C}$ using a Turbovap $\mathrm{LV}$ and resuspended in aqueous methanol-water $(80 \% \mathrm{v} / \mathrm{v}$, $500 \mu \mathrm{l})$. The sample was filtered through a $0.2 \mu \mathrm{m}$ pore 
size PVDF centrifugal filter $(14000 \times g, 2 \mathrm{~min})$ prior to analysis using liquid chromatography-mass spectrometry (LC-MS) or advanced liquid chromatographytandem mass spectrometry (LC-MS/MS) for spirolides (SPX) and other lipophilic shellfish toxins (LC-MS).

Toxin analysis. A spirolide desmethyl $\mathrm{C}$ standard was purchased from the National Research Council Institute for Marine Bioscience (NRC IMB, Halifax, NS, Canada) and a range of calibration solutions $(2.5$ to $40 \mathrm{ng} \mathrm{ml}^{-1}$ ) was prepared by dilution in $80 \% \mathrm{v} / \mathrm{v}$ methanol-water. In 2007, SPX analysis was carried out using an Agilent 1100 series HPLC system comprising a G1323B control module, a G1354A quaternary pump, a G1379A degasser and a G1313A autosampler. The detector used was an Applied Biosystems API 150EX mass spectrometer equipped with a TurboIonspray ${ }^{\circledR}$ atmospheric pressure ion source (Applied Biosystems). Chromatographic separation was achieved using a Thermo Hypersil $\mathrm{C}_{8}$ BDS column $(50 \times 2.1 \mathrm{~mm}$, particle size $3 \mu \mathrm{m}$ with $10 \mathrm{~mm}$ guard of same material). The analysis was performed under isocratic conditions $(65 \%$ A, $35 \%$ B). Eluent $\mathrm{A}$ was water and B was acetonitrile-water (95:5), both containing $2 \mathrm{mM}$ ammonium formate and $50 \mathrm{mM}$ formic acid. Flow rate, analysis run time, injection volume and column temperature were $0.25 \mathrm{ml} \mathrm{min}^{-1}, 10 \mathrm{~min}, 5 \mu \mathrm{l}$ and $20^{\circ} \mathrm{C}$, respectively.

For the analysis, the MS was operated in positive ion and selected ion monitoring (SIM) modes after flow injection analysis (FIA) and optimisation of MS parameters using an automated software programme (Analyst v1.1, Applied Biosystems). A switching valve was used to divert the mobile phase to waste for the first 2.5 min of the analytical run to avoid the introduction of matrix interferences. The following source conditions were applied: drying gas (nitrogen) $7.51 \mathrm{~min}^{-1}$, nebuliser gas setting (nitrogen) 11, gas temperature $450^{\circ} \mathrm{C}$ and ion spray voltage $4000 \mathrm{~V}$.

The SIM method monitored for the presence of the molecular ion $[\mathrm{M}+\mathrm{H}]^{+}$formed in the source for a selection of spirolide analogues with mass-to-charge ratios $(\mathrm{m} / \mathrm{z})$ of 692.6 for SPX A, 694.5 for SPX B, 706.5 for SPX C, 708.5 for SPX D, 692.6 for SPX desMe-C and 694.5 for SPX desMe-D. A couple of fragment ions (m/z 444.1 and 164.2) were also monitored to confirm the presence of the SPX analogues. Dwell time for all ions was $200 \mathrm{~ms}$. The declustering potential (DP) and focusing potential (FP) were 50 and $325 \mathrm{~V}$, respectively, for the SPXs, but were slightly higher for the fragment ions m/z 444.1 and 164.2 (DP: 80 and $90 \mathrm{~V}$, FP: 325 and $350 \mathrm{~V}$, respectively).

In 2008, spirolide toxins analyses were carried out using a 3200 QTrap ${ }^{\circledR}$ hybrid triple quadrupole-linear ion trap mass spectrometer (MS/MS) equipped with an electrospray Turbo $\mathrm{V}^{\circledR}$ ion source supplied by
Applied Biosystems. The MS/MS was coupled to an Agilent 1200 series LC comprising of a degasser, binary pump, column oven and autosampler. Screening, confirmation and quantification of SPXs were performed simultaneously as described in Brown et al. (2011). In both 2007 and 2008, other lipophillic shellfish toxins were analysed by LC-MS according to Stobo et al. (2005).

Statistical analyses. The statistical analyses were performed using SPPS Version 15.0 for Windows. Oneway ANOVA followed by Tukey's post hoc test (Tukey 1949) was performed to identify significant differences in the Alexandrium ostenfeldii concentrations found in water basins of Cork Harbour during summer 2006. The data were tested for normality and homogeneity of variance prior to performing the post hoc test. Independent-sample Student's $t$-tests (Student 1908) were used to compare: (1) the vertical and horizontal A. ostenfeldii concentrations in the North Channel during the summers of 2006 and 2007, and (2) the spirolide toxin contents of passive samplers deployed in the North Channel of Cork Harbour during the summers of 2007 and 2008.

\section{RESULTS}

\section{Probe specificity and dual labelling assay testing}

The rDNA multiple sequence alignments carried out with Irish strains of Alexandrium ostenfeldii and A. peruvianum, and data imported from GenBank, showed that the 2 taxa were homologous in the sequence region of the probe Ost/Peru-J whereas a 1 to 3 nucleotide mismatch was visible between the 2 taxa for the probe Ost-I (Fig. 2). The probe Ost-I was homologous to SSU rDNA sequences of $A$. ostenfeldii strains from Ireland (BY.K04) and Denmark (K0287). One mismatch was visible with $A$. peruvianum from Ireland (LS.D05) and A. ostenfeldii from Canada (AOSH1), 2 mismatches with A. ostenfeldii from New Zealand (BAHME136) and A. tamutum (SZN29), and 3 or more mismatches with other Alexandrium species, including A. minutum. The probe Ost/Peru-J was homologous to LSU rDNA sequences of $A$. ostenfeldii strains from Denmark (K0324), Ireland (BY.K04), Finland (AOTVA4) and New Zealand (BAHME136), as well as $A$. peruvianum from Ireland (LS.D05) and Spain (IEO-VGOAM10C). The probe had one mismatch with a strain of $A$. ostenfeldii from Canada (AOSH1) and A. minutum (95/4), 2 mismatches with A. tamutum (SZN29) and over 5 mismatches with other Alexandrium species.

Fluorescent signals were detected after simultaneous hybridisations of both probes with cultured cells of A. ostenfeldii and A. peruvianum (Fig. 3). Cross- 


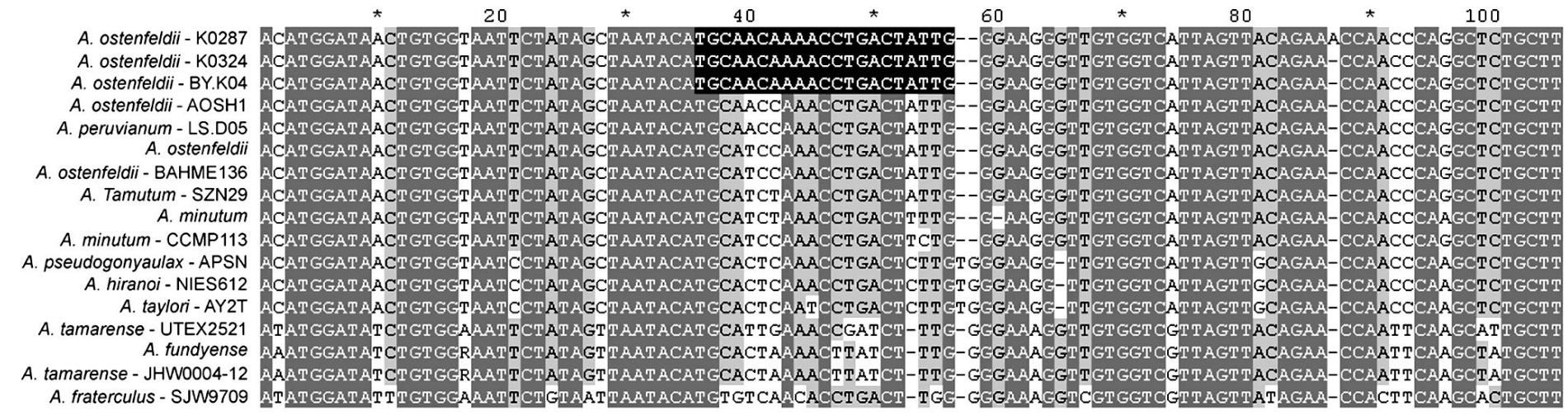

Fig. 2. Alexandrium spp. Multiple nucleotide sequence alignment of the SSU rDNA region of Alexandrium spp. strains. The black region indicates the target site of the probe Ost.I. When available, the strain code is indicated on each line after the species designation

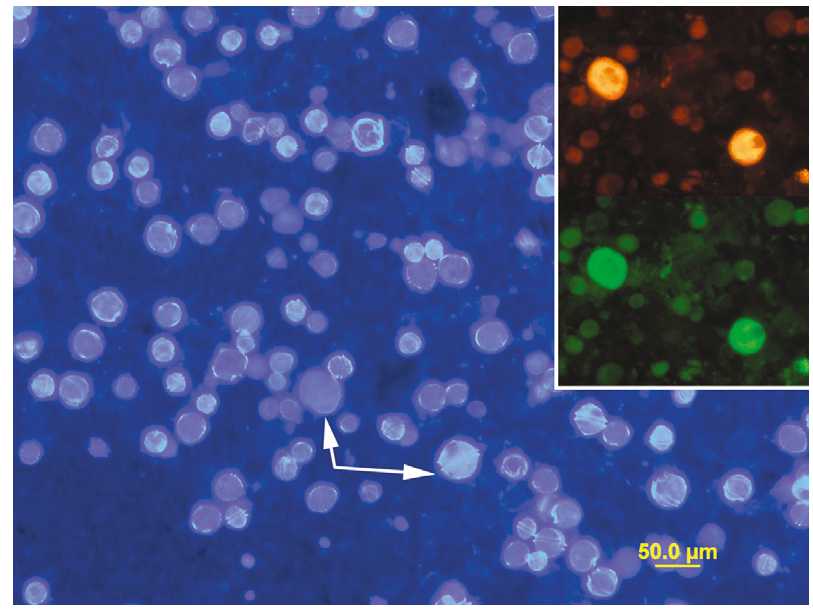

Fig. 3. Alexandrium ostenfeldii. Epifluorescence images of a field sample from Cork Harbour containing A. ostenfeldii cells labelled with the probes Ost/Peru-J (orange) and Ost-I (green). The main panel shows cells stained with calcofluor under UV fluorescence. Arrows indicate the A. ostenfeldii cells labelled with the probes; these cells are shown in the 2 side panels

reactivity tests were carried out using a panel of Alexandrium spp. and dinoflagellate species commonly found in northwest European coastal waters; hybridisation was negative and showed weak residual pigment autofluorescence (data not shown). In addition, no matrix effect or cross-reactivity with other phytoplankton was observed after performing probe hybridisation with natural samples. The enumeration of labelled cells was rapid at $\times 200$ magnification. The simultaneous use of calcofluor often enabled the confirmation of cell identifications through the examination of morphological features of the thecae, in particular the shape of the first apical plate.

\section{Morphological description of Alexandrium ostenfeldii}

Alexandrium ostenfeldii was detected by FISH each summer (2006 to 2008) during weekly sampling in Cork Harbour. No signal was recorded for $A$. peruvianum in any of the field samples analysed. Fluorescently labelled $A$. ostenfeldii cells were solitary and displayed a slightly compressed anteroposterior shape. The cells ranged in size from 31.3 to $49.7 \mu \mathrm{m}$. The mean cell diameter was $38.7 \mu \mathrm{m}(\mathrm{n}=77, \mathrm{SD}=4.6)$. The morphology of labelled cells was simultaneously examined using the fluorescent filter set for calcofluor to confirm the FISH diagnostics. When cells were correctly oriented between the membrane and the coverslip, their plate tabulation was characteristic of
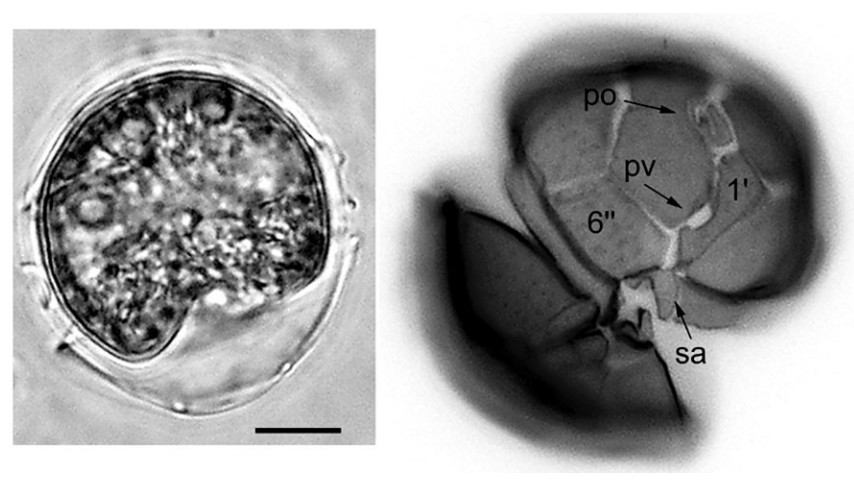

Fig. 4. Alexandrium ostenfeldii. Light and epi-fluorescence micrographs (left and right, respectively) of cells from Cork Harbour showing the cell morphology and arrangement of thecal plates. Plate abbreviations are as follows: first apical plate $\left(1^{\prime}\right)$, sixth precingular plate $\left(6^{\prime \prime}\right)$, apical pore (po), ventral pore (pv) and sulcal anterior plate (sa). Scale bar $=10 \mu \mathrm{m}$ 
A. ostenfeldii/peruvianum, with the existence of a typical large and truncated ventral pore on the right margin of the first apical plate and the presence of a widerthan-long sixth (6") precingular plate (Fig. 4). The shape of the sulcal anterior plate varied amongst the specimens observed, showing at times a nearly triangular arrangement or a more asymmetric pattern with a left extension.

\section{Abundance and distribution of Alexandrium ostenfeldii in Cork Harbour}

The taxa-specific probes facilitated the detection and quantification of Alexandrium ostenfeldii in samples, which contained high levels of morphologically similar non-target taxa such as Alexandrium spp., Scrippsiella sp. or Gonyaulax sp. In Cork Harbour, A. ostenfeldii co-occurred with A. minutum and A. tamarense, but in much lower proportions. The mean contribution of $A$. ostenfeldii to the Alexandrium sp. community was $\sim 0.6 \%$ ( $\mathrm{n}=13, \mathrm{SD}=1.3$ ) in 2008 and $\sim 0.3 \%$ in 2006 and 2007 ( $\mathrm{n}=32, \mathrm{SD}=0.2$, and $\mathrm{n}=36$, $\mathrm{SD}=0.7$, respectively). A similarity in the general dynamics of $A$. ostenfeldii, A. minutum and A. tamarense was observed in the North Channel for 2006 and 2007 in particular (Fig. 5). Mean cell concentrations rose following a spring tide in early/mid-June during both summers, with the respective maxima found on 20 and 14 June. The mean maximum $A$. ostenfeldii cell concentrations reached in the North Channel were

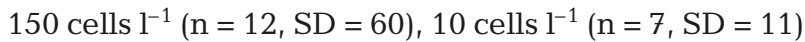

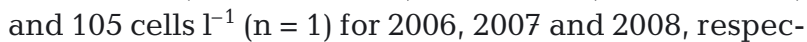
tively. Locally, the maximum A. ostenfeldii cell concentrations were observed in the middle portion of the North Channel on 15 June 2006 with 211 cells $\mathrm{l}^{-1}$, which also coincided with the peak of Alexandrium spp. abundance. Weekly surveys were carried out in the entire domain of Cork Harbour in 2006. The surface cell density of $A$. ostenfeldii was significantly higher in the North Channel than in the main harbour and Lough Mahon (ANOVA, $F=12.2$, p < 0.05) when the weekly maximum concentration reached levels greater than 100 cells $\mathrm{l}^{-1}$ (15 and 22 June). The vertical distribution of the species was assessed in the North Channel in 2006 and 2007. Considering the stations where cells were present at levels greater than 5 cells $\mathrm{l}^{-1}$, A. ostenfeldii concentrations were not significantly higher in the 0 to $1 \mathrm{~m}$ depth domain than in the deeper domains ( $t$-test, $\mathrm{p}>0.10$ ). The horizontal distribution of A. ostenfeldii was also examined in the North Channel after grouping the geographic locations sampled into east and west compartments. No significant difference was found in the mean surface concentration in those areas ( $t$-test, p > 0.10) in 2006 or 2007.

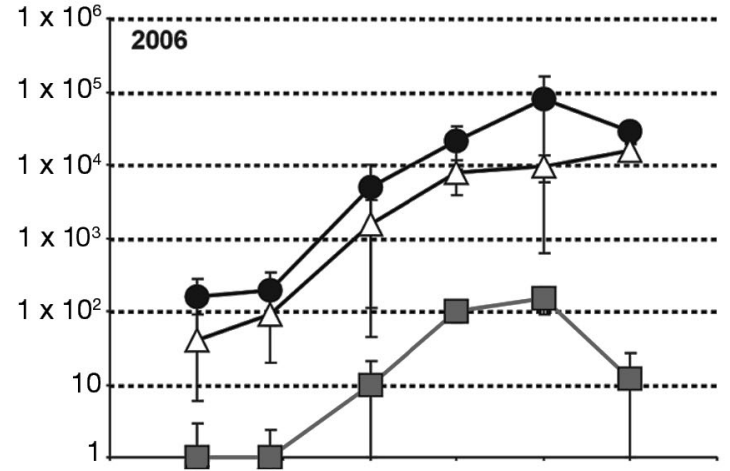

18-05 25-05 01-06 08-06 15-06 22-06 29-06 06-07
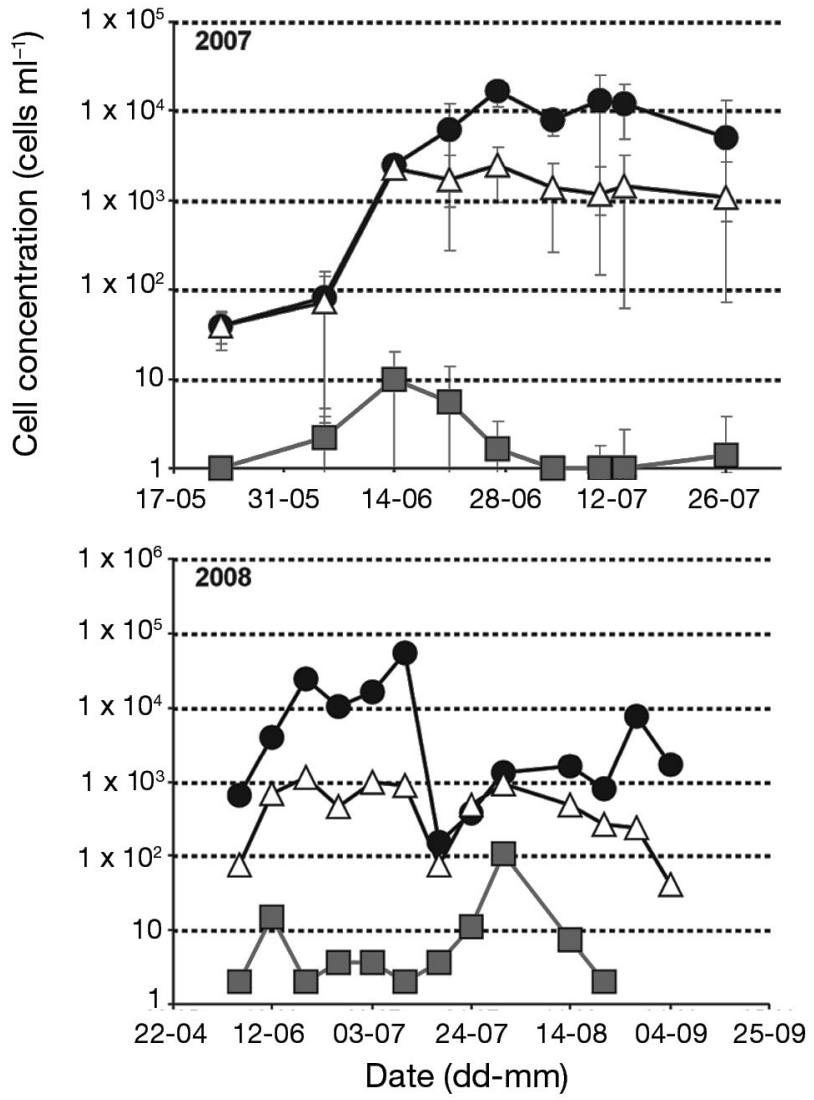

Fig. 5. Alexandrium spp. Mean A. minutum (O), A. tamarense $(\triangle)$ and A. ostenfeldii $(\square)$ concentrations in the North Channel area of Cork Harbour derived for each survey carried out during the summers of 2006, 2007 and 2008. Only one station was weekly sampled in 2008. Error bars are \pm SD

\section{Toxin analysis of SPATT passive samplers}

Spirolide 13-desmethyl C was detected using LC-MS in all the passive samplers deployed from June to August 2007 (n = 8) along with okadaic acid, dinophysistoxin-2 and pectenotoxin-2. Additionally, low concentrations of pectenotoxin-2 seco acid and azaspiracid 1 were also retrieved from the resins. A rela- 

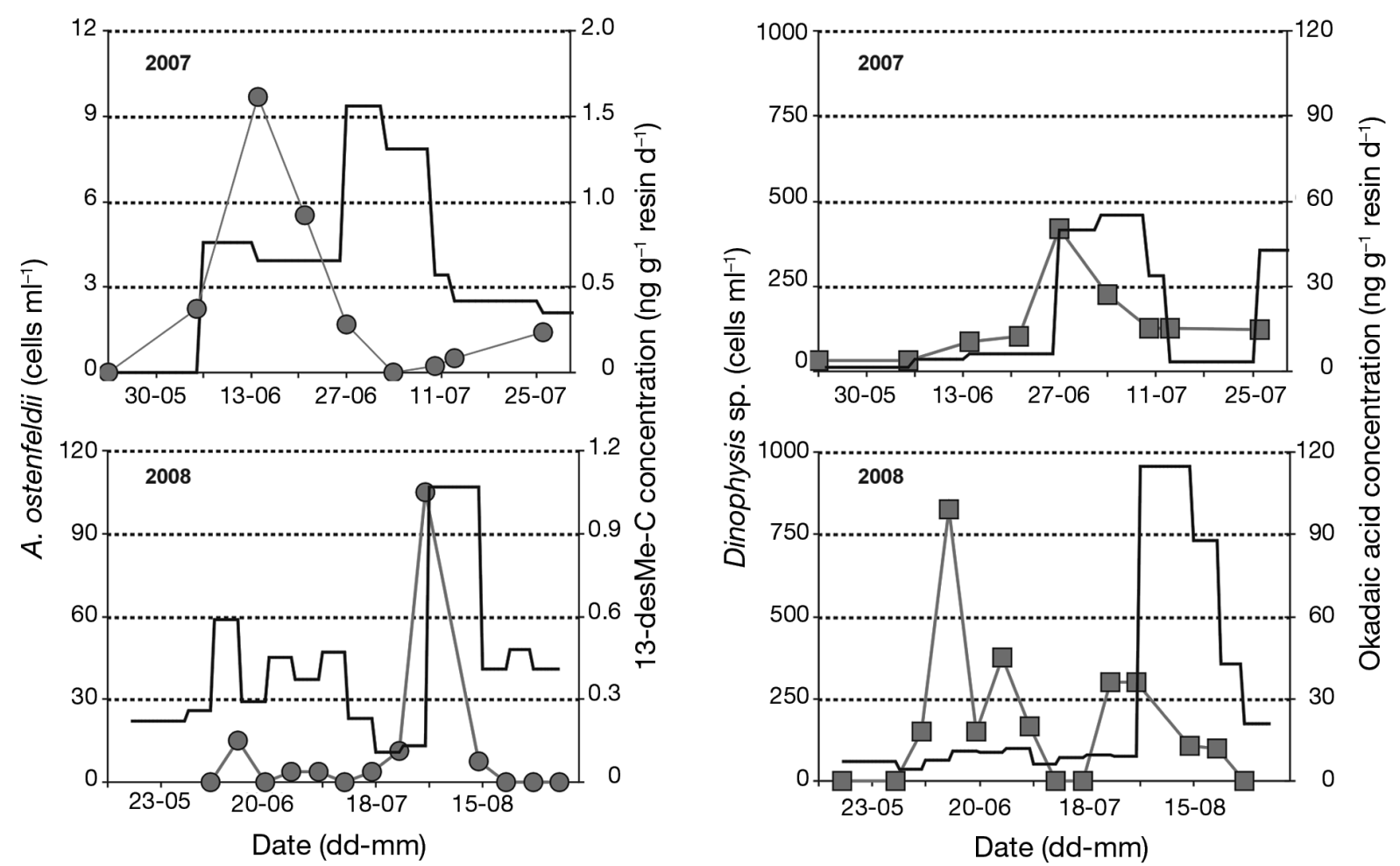

Fig. 6. Alexandrium ostenfeldii and Dinophysis sp. abundances (symbols and grey lines), and spirolide 13-desmethyl C (13desMe-C) and okadaic acid concentrations (solid lines) in passive samplers deployed in the North Channel area of Cork Harbour during the summers of 2007 and 2008

tively good congruence was observed in the dynamics of adsorbed spirolide toxins and Alexandrium ostenfeldii cell concentrations as determined by FISH (Fig. 6). The maximum spirolide 13-desmethyl C concentration determined was $1.56 \mathrm{ng} \mathrm{g}^{-1} \mathrm{~d}^{-1}$; this occurred after the $A$. ostenfeldii cell concentration peak was reached on 14 June. Spirolide 13-desmethyl $\mathrm{C}$ was, in this case, detected even though no A. ostenfeldii cells were found by FISH at the time the sachet was retrieved from the North Channel.

Similarly to 2007, spirolides were detected in all resins in $2008(n=14)$, although the period sampled was longer and spanned from May to early September. In 2008, LC-MS/MS was available and both spirolide 13-desmethyl C and 20-methyl SPX G were recorded in all resin extracts, even when no Alexandrium ostenfeldii cells were detected by FISH (Fig. 7). The lipophilic toxins okadaic acid, dinophysistoxin-2 and pectenotoxins were again identified in the samplers. The maximum combined spirolide concentration (2.5 $\mathrm{ng} \mathrm{g}^{-1} \mathrm{~d}^{-1}$ ) was observed for the 31 July to 14 August period, which coincided with the maximum A. ostenfeldii cell concentration (105 cells $\left.\mathrm{l}^{-1}\right)$. Overall and only considering 13-desmethyl $\mathrm{C}$, there was no significant difference between the spirolide concentration found in the passive samplers in 2007 and 2008 ( $t$-test, $\mathrm{p}>0.14)$ nor in the toxin background levels $(t$-test, $\mathrm{p}>0.15)$. However, maximal values for both years were significantly higher than the respective mean background levels ( $t$-test, $\mathrm{p}<0.01)$.

\section{DISCUSSION}

The occurrence of spirolide-producing Alexandrium ostenfeldii and $A$. peruvianum in Ireland has previously been ascertained on the southwest and north coasts, respectively, from resting cysts isolated from surface sediments (Touzet et al. 2008a). Discrimination between vegetative forms of the 2 taxa is morphologically complex and mainly relies on the examination of minor differences in the shapes of sulcal plates (Balech 1995). In recent studies, partial sequencing and phylogenetic analysis of the ribosomal genes have supported the separation of the taxa, if not into different species, at least into potential ribotypes (Touzet et al. 2008a, Kremp et al. 2009). Reliable discrimination between the 2 taxa must therefore rely on the use of specific molecular markers. Addressing species boundaries with more certainty will require the analysis of additional strains from various geographical locations and the study of mating interactions (Destombe \& Cembella 1990, Lilly et al. 2007, Brosnahan et al. 2010). 


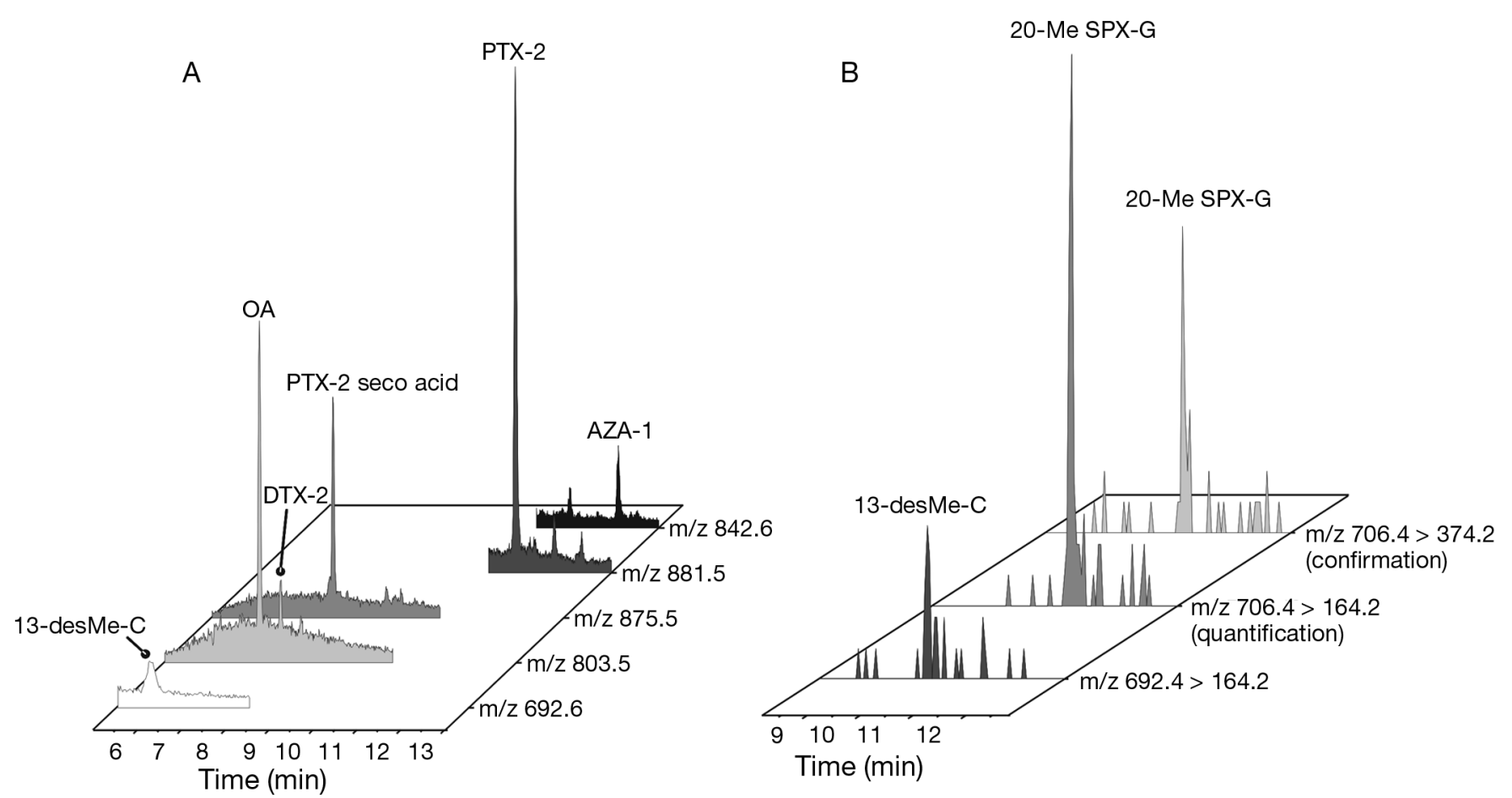

Fig. 7. Chromatograms of solid-phase adsorption toxin tracking (SPATT) resin extracts. (A) LC-MS selected ion monitoring chromatograms of spirolide 13-desmethyl C (13-desMe-C) and lipophilic shellfish toxins from a SPATT resin extract (deployed 14 to 27 June 2007). (B) LC-MS/MS Multiple Reaction Monitoring chromatograms of spirolide analogues from a SPATT resin extract (deployed 19 to 6 June 2008)

Whole-cell FISH used with calcofluor can facilitate the selective detection in environmental samples of taxa of interest together with various armoured dinoflagellates (Anderson et al. 2005). The dual labelling assay designed in the present study enabled the simultaneous detection of both Alexandrium ostenfeldii and A. peruvianum in mixed cultures. Difficulties arose in developing probes targeting specifically either one or both taxa. Preliminary trials using $\sim 15$ probes in both the SSU and LSU regions of the rDNA gene proved inconclusive (data not shown). This could be due to the structural folding of the RNA, preventing access to binding sites or to weak fluorescent signals masked by histone-like proteins (Inácio et al. 2003). Database interrogation showed some degree of selectivity of the probes with respect to $A$. ostenfeldii and $A$. peruvianum strains from various origins. The relatively low number of both taxa currently maintained in culture collections may necessitate the re-design of molecular assays when additional strains are genetically characterised, and may reveal regional polymorphism.

The presence of Alexandrium ostenfeldii was successfully confirmed in Cork Harbour by morphological and genetic-based analyses during 3 successive summers. However, at no stage was A. peruvianum detected in the water samples; all FISH-labelled cells exhibited both orange and green fluorescence, a diagnostic indicator of $A$. ostenfeldii. The FISH- derived cell counts could not be calibrated against a traditional enumeration method as the combination of low A. ostenfeldii concentration and high amounts of other Alexandrium spp. cells prevented this. Previous results obtained using the same methodology and targeting smaller-sized Alexandrium spp. have shown that a 1.5 underestimation factor can occur (Touzet et al. 2008b). The recovery of $A$. ostenfeldii from the water samples by backwashing is likely to have been greater because of the larger cell size of specimens. A. ostenfeldii often occurs at relatively low cell densities but can also reach bloom concentrations greater than $1 \times 10^{5}$ cells $1^{-1}$ (Kremp et al. 2009). In the present study, the cell concentrations of $A$. ostenfeldii were always low $\left(<150\right.$ cells $\left.1^{-1}\right)$ and were often well below the detection limit of light microscopy methods. This can be problematic for monitoring as Alexandrium spp. typically contribute to a small proportion of phytoplankton assemblages. Similarly to Gribble et al. (2005), the use of concentrated seawater samples with FISH allowed the detection of cells at low concentrations $\left(\sim 3\right.$ cells $\left.\mathrm{l}^{-1}\right)$. However, the constraint for sample processing within $24 \mathrm{~h}$ using a protocol coupled with substantial health and safety requirements does make the methodology unsuitable for shellfish farmers, who may have to collect and mail water samples to official monitoring agencies in some countries. 
Cork Harbour is one of several estuaries located along the Atlantic coastline of Europe that harbours PSP toxin-producing populations of Alexandrium sp. (Probert 1999, Hansen et al. 2003, Franco et al. 1994, Nascimento et al. 2005, Touzet et al. 2008b, Brown et al. 2011). A. ostenfeldii concentrations were highest in the North Channel, similar to concentrations of A. minutum and A. tamarense, which co-occur annually in Cork Harbour (Touzet et al. 2008b). A previous study has suggested that the intensity of Alexandrium blooms in the area is controlled by the balance between temperature- and irradiance-dependent growth rate and tidal dilution (Ní Rathaille 2007). Although several orders of magnitude lower in cell concentration, and given the substantial variability in the Alexandrium spp. distribution in the North Channel, variations in the mean abundance of $A$. ostenfeldii coincided surprisingly well with those of $A$. minutum and $A$. tamarense. Physical forcing has been shown to be essential in influencing the water column dynamics of phytoplankton in the North Channel of Cork Harbour (Ní Rathaille et al. 2008). The apparent similarity in the individual dynamics of Alexandrium spp. observed in the present study suggests they may share a common ecological niche, or at least respond in a comparable way to changes in their environment. The timing of Alexandrium spp. blooms is generally set to occur after the first spring tide in June, when the tidal dilution over a complete spring-neap cycle is at its weakest and both irradiance and temperature are relatively high (Ní Rathaille et al. 2009). It is also possible that synchronous hatching of resting cysts of Alexandrium spp., may explain the resemblance in Alexandrium spp. dynamics in the water column as suggested for $A$. fundyense in the Gulf of Maine (Anderson \& Keafer 1987). Laboratory-based experiments carried out with A. minutum and A. tamarense strains isolated in Cork Harbour have shown similarities in the excystment dynamics of both species at 15 to $20^{\circ} \mathrm{C}$ with, in particular, maximal excystment rate occurring between April and July (Ní Rathaille 2007). The lack of similar data for A. ostenfeldii at present prevents the support of the synchronous germination hypothesis to explain the apparently matching dynamics of planktonic populations.

The deployment of SPATT passive samplers has been recently introduced for the passive adsorption of lipophilic biotoxins near shellfish aquaculture production areas (Mackenzie et al. 2004). A variety of resin polymers has been tested for such purposes (Fux et al. 2008) and the selection of the SPEABEADS ${ }^{\circledR}$ SP700 resin was based on previous evaluation by Turrell et al. (2007). Spirolides and other lipophilic toxins, including okadaic acid, azaspiracids, dinophysistoxins and pectenotoxins, were detected after analysis of SPATT bags deployed in Cork Harbour during the summers of 2007 and 2008. A similar suite of toxins was previously detected using the Diaion ${ }^{\circledR} \mathrm{HP}-20$ resin in other locations along the Irish coastline and in Norway (Fux et al. 2009, Rundberget et al. 2009). The comparison of toxin amounts retrieved from the sachets with those of other studies is difficult because of differences in deployment approaches and expression of results. In the present study, the samplers were deployed for uneven time intervals because of operational constraints, and the amount of toxin per quantity of resin was standardised over the length of deployment. Analysis of resin and seawater samples showed a similarity in the evolution patterns of adsorbed spirolides and Alexandrium ostenfeldii cell concentrations, albeit with a differential step of several days in 2007. Commenting upon the relationship between cellular toxin quotas and toxin content in samplers is premature given the lack of laboratory-based data on the topic but, assuming that SPXs originated from $A$. ostenfeldii only, the intracellular toxin quotas may have varied between different sampling conditions. However, saturation of the resins with other compounds may also have occurred, suggesting that shorter deployment intervals may be more appropriate for comparisons in future field studies. Other possible reasons could include higher proportions of uncharacterised spirolide variants in 2008 or great variability in the spatial distribution of A. ostenfeldii during the time intervals the samplers were deployed.

Passive samplers can reveal the presence of certain species and/or populations of biotoxin-producing microalgae based on the composition of the in situ toxin profile, and may therefore prove valuable for biogeographical studies. Separate analysis of passive samplers deployed in the southwest of Ireland and of an Alexandrium ostenfeldii cultured strain from the same area previously identified spirolide 13 desmethyl-C (Touzet et al. 2008a, Fux et al. 2009), as did the present study with samples from Cork Harbour. The detection of background toxin levels and quantifiable increases associated with toxic phytoplankton development show potential for monitoring. Weekly deployment of passive samplers is unsuitable for forecasting as the associated low resolution is not indicative of the recent in situ situation. However, high-frequency sampling and toxin analysis in an operational monitoring programme would require high cost-effectiveness. Results from a recent study suggest that deployed resins may not enable the forecasting of shellfish contamination as toxin concentration increases occur simultaneously in shellfish and the passive samplers (Fux et al. 2009). Future work should aim to determine, for selected toxins, a minimum threshold value to use as an indicator of likely toxic event occurrence. This value would need to be significantly greater than background toxin con- 
centrations and well below levels that render shellfish unsafe for human consumption.

Alexandrium minutum strains from Cork Harbour produce gonyautoxins 2 and 3 whereas the cooccurring variety of $A$. tamarense, also known as west European ribotype (or Group III; Lilly et al. 2007), is nontoxic (Touzet et al. 2008a). Given the high potency of saxitoxins towards mammals, the development of a resin preferentially targeting those compounds is urgent. Low amounts of C-toxins have recently been detected in field samples collected in Cork Harbour (Touzet et al. 2010). This could be due to the presence of an additional undetected chemotype of A. minutum in the area. Considering that PSP toxins have been found in several cultured strains of $A$. ostenfeldii from various locations (Hansen et al. 1992, Mackenzie et al. 1996, McKinnon et al. 2004), it is possible that the local A. ostenfeldii population from Cork Harbour may produce such compounds too, even though saxitoxins were not found in the only Irish strain originating from the southwest coast (Touzet et al. 2008a). The isolation of local strains is hence required but difficulties reside in the fact that $A$. ostenfeldii is a very minor component of the dinoflagellate assemblage in the estuary. Future isolation and germination of resting cysts from surface sediments may facilitate the generation of cultures.

The results obtained in Cork Harbour for spirolides in 2007 and 2008 showed that an increase in toxin concentration in the water column could be detected even at phytoplankton concentrations well below the detection threshold of common light microscopy techniques. This indicates that the sensitivity of the samplers is very high or that there might potentially be other SPXproducing species. As biotoxin monitoring of shellfish is carried out on an irregular basis in the area, according to the interpretation of local HAB species concentrations, the toxin levels determined from the passive samplers cannot be compared with those obtained from shellfish tissue analysis. SPXs are fast-acting toxins that do not fall under any current regulation. However, for comparison purposes and using oversimplistic calculations based on toxin quotas derived from laboratory-based experiments (Maclean et al. 2003), the maximum observed Alexandrium ostenfeldii concentration in Cork Harbour, constant mussel physiology attributes and excluding tidal dilution effects, SPX levels may have reached the threshold limit set for saxitoxin (80 $\mathrm{\mu g}$ per $100 \mathrm{~g}$ tissue) within $10 \mathrm{~d}$ in 2008. The co-occurrence of spirolides with other potent lipophilic and PSP toxins near shellfish farming operation sites also requires more attention. Even though individual biotoxins may be detected at levels below regulation, there could be a potential risk toward human health safety because of the presence of multiple toxins. The importance of toxicological effects attributable to potential synergism between biotoxins will necessitate further investigation using ethically controversial rodent bioassays or nerve and gastrointestinal mammalian cell lines.

\section{CONCLUSIONS}

The present study reports the concomitant detection of Alexandrium ostenfeldii with spirolides in Irish coastal waters from the use of a dual FISH assay and passive biotoxin samplers. The molecular assay should enable the reliable mapping of $A$. ostenfeldii/peruvianum populations to investigate biogeographical aspects relative to those taxa, in particular in northwest Europe. The sensitivity of the methodologies, when coupled with high-resolution sampling, may facilitate the development of forecasting capacities of toxic blooms and prove valuable in supporting existing monitoring programmes. The co-occurrences of several biotoxin-producing phytoplankton species require the consideration of the potential risk of synergetic effects when determining the safety status of shellfish products, which may accumulate several toxins in their tissues.

Acknowledgements. The authors acknowledge D. HughJones, B. Byrne and D. Geary for the use of their on-site facilities and the provision of boats. Thanks are due to A. Ní Rathaille, S. Lyons, H. Farrell, B. Gleeson and B. Kennedy for field sampling and lab assistance. This work was supported by the EC 6th Framework Programme through the Interreg NWE IIIB 'FINAL' (G142), the Collective Research Project SPIES-DETOX (Coll CT 2006, Contract no: 030270) and the SEED (GOCE-CT-2005-003375) project.

\section{LITERATURE CITED}

Altschul SF, Gish W, Miller W, Myers EW, Lipman DJ (1990) Basic Local Alignment Search Tool. J Mol Biol 215: 403-410

Andersen P, Enevoldsen H, Anderson DM (2003) Harmful algal monitoring programme and action plan design. In: Hallegraeff GM, Anderson DM, Cembella AD (eds) Manual on harmful marine microalgae. UNESCO, Paris

Anderson DM (1998) Physiology and bloom dynamics of toxic Alexandrium species, with emphasis on life cycle transitions. In: Anderson DM, Cembella AD, Hallegraeff GM (eds) Physiological ecology of harmful algal blooms. NATO AS1 Series, Vol. G41, Springer-Verlag, Berlin, Heidelberg

Anderson DM, Keafer BA (1987) An endogenous annual clock in the toxic marine dinoflagellate Gonyaulax tamarensis. Nature 325:616-617

Anderson DM, Kulis D, Keafer BA, Gribble KE, Marin R, Scholin CA (2005) Identification and enumeration of Alexandrium spp. from the Gulf of Maine using molecular probes. Deep Sea Res II 52:2467-2490

Balech E (1995) The genus Alexandrium Halim (Dinoflagellata). Sherkin Island Marine Station Publication, Sherkin 
Island, Co. Cork, Ireland

Brosnahan ML, Kulis DM, Percy L, Lewis J, Erdner DL, Solow A, Anderson DM (2010) Outbreeding lethality between toxic, Group I and non-toxic, Group III Alexandrium tamarense spp. isolates: predominance of heterotypic encystment and implications for mating interactions and biogeography. Deep-Sea Res Part II 57:175-189

Brown L, Bresnan E, Graham J, Lacaze JP, Turrell E, Collins C (2011) Distribution, diversity and toxin composition of the genus Alexandrium (Dinophyceae) in Scottish waters. Eur J Phycol 45(4):375-393

Cembella AD, Quilliam MA, Lewis NI, Bauder AG, Right JLC (1998) Identifying the planktonic origin and distribution of spirolides in coastal Nova Scotian waters. In: Reguera B, Blanco J, Fernandez ML, Wyatt T (eds) Harmful algae. Xunta de Galicia and IOC of UNESCO, Santiago de Compostela, Spain

Cembella AD, Lewis NI, Quilliam MA (2000) The marine dinoflagellate Alexandrium ostenfeldii (Dinophyceae) as the causative organism of spirolides shellfish toxins. Phycologia 39:67-74

Cembella AD, Bauder AG, Lewis NI, Quilliam MA (2001) Association of the gonyaulacoid dinoflagellate Alexandrium ostenfeldii with spirolide toxins in size-fractionated plankton. J Plankton Res 23:1413-1419

Destombe C, Cembella AD (1990) Mating-type determination, gametic recognition and reproductive success in Alexandrium excavatum (Gonyaulacales, Dinophyta), a toxic redtide dinoflagellate. Phycologia 29:316-325

> Diercks S, Medlin LK, Metfies K (2008) Colorimetric detection of the toxic dinoflagellate Alexandrium minutum using sandwich hybridization in a microtiter plate assay. Harmful Algae 7:137-145

FAO (2004) Marine biotoxins. FAO Food and Nutrition Paper, 80. Food and Agriculture Organization of the United Nations, Rome

- Franco JM, Fernandez P, Reguera B (1994) Toxin profiles of natural populations and cultures of Alexandrium minutum Halim from Galician (Spain) coastal waters. J Appl Phycol 6:275-279

> Fritz L, Triemer RE (1985) A rapid simple technique utilizing Calcofluor White M2R for the visualization of dinoflagellate thecal plates. J Phycol 21:662-664

Fux E, Marcaillou C, Mondeguer F, Bire R, Hess P (2008) Field and mesocosm trials on passive sampling for the study of adsorption and desorption behaviour of lipophilic toxins with a focus on OA and DTX1. Harmful Algae 7:574-583

$>$ Fux E, Bire R, Hess P (2009) Comparative accumulation and composition of lipophilic marine biotoxins in passive samplers and in mussels ( $M$. edulis) on the west coast of Ireland. Harmful Algae 8:523-537

GEOHAB (2001) Global ecology and oceanography of harmful algal blooms. In: Glibert P, Pitcher G (eds) Science Plan. SCOR and IOC, Baltimore and Paris

> Gescher C, Metfies K, Medlin LK (2008) The ALEX CHIOP: development of a DNA chip for identification and monitoring of Alexandrium. Harmful Algae 7:485-494

Gribble KE, Keafer BA, Quilliam MA, Cembella AD, Kulis DM, Manahan A, Anderson DM (2005) Distribution and toxicity of Alexandrium ostenfeldii (Dinophyceae) in the Gulf of Maine, USA. Deep-Sea Res II 52:2745-2763

Guillard R (1975) Culture of phytoplankton for feeding marine invertebrates. In: Smith W, Chanley M (eds) Culture of marine invertebrate animals. Plenum Press, New York, p 29-60

$>$ Hansen PJ, Cembella AD, Moestrup Ø (1992) The marine dinoflagellate Alexandrium ostenfeldii: paralytic shellfish toxin concetration, composition, and toxicity to a tintinnid ciliate. J Phycol 28:597-603

Hansen G, Daugbjerg N, Franco JM (2003) Morphology, toxin composition and LSU rDNA phylogeny of Alexandrium minutum (Dinophyceae) from Denmark, with some morphological observations on other European strains. Harmful Algae 2:317-335

- Hosoi-Tanabe S, Sako Y (2004) Rapid detection of natural cells of Alexandrium tamarense and A. catenella (Dinophyceae) by fluorescence in situ hybridization. Harmful Algae 4:319-328

Inácio J, Behrens S, Fuchs BM, Fonseca A, Spencer-Martins I, Amann R (2003) In situ accessibility of Saccharomyces cerevisiae 26S rRNA to Cy3-labelled oligonucleotide probes comprising the D1 and D2 domains. Appl Environ Microbiol 69:2899-2905

John U, Cembella AD, Hummert C, Elbrachter M, Groben R, Medlin L (2003) Discrimination of the toxigenic dinoflagellates Alexandrium tamarense and A. ostenfeldii in cooccurring natural populations from Scottish coastal waters. Eur J Phycol 38:25-40

John U, Medlin LK, Groben R (2005) Development of specific rRNA probes to distinguish between geographic clades of the Alexandrium tamarense species complex. J Plankton Res 27:199-204

Kim CJ, Kim CH, Sako Y (2005) Development of a molecular identification method for the genus Alexandrium (Dinophyceae) using whole-cell FISH. Mar Biotechnol 7: 215-222

Kremp A, Lindholm T, Dreßler N, Erler K, Gerdts G, Eirtovaara S, Leskinen E (2009) Bloom forming Alexandrium ostenfeldii (Dinophyceae) in shallow waters of the Åland Archipelago, Northern Baltic Sea. Harmful Algae 8: 318-328

Lazerges M, Perrot H, Antoine E, Defontaine A, Compere C (2006) Oligonucleotide quartz crystal microbalance sensor for the microalgae Alexandrium minutum (Dinophyceae). Biosens Bioelectron 21:1355-1358

> Lenaers G, Maroteaux L, Michot B, Herzog M (1989) Dinoflagellates in evolution. A molecular phylogenetic analysis of large subunit ribosomal RNA. J Mol Evol 29:40-51

Lilly E, Halanych KM, Anderson DM (2007) Species boundaries and global biogeography of the Alexandrium tamarense complex (Dinophyceae). J Phycol 43:1329-1338

> Lim PT, Usup G, Leaw CP, Ogata T (2005) First report of Alexandrium taylori and Alexandrium peruvianum (Dinophyceae) in Malaysia waters. Harmful Algae 4:391-400

> Mackenzie L, White D, Oshima Y, Kapa J (1996) The resting cyst and toxicity of Alexandrium ostenfeldii (Dinophyceae) in New Zealand. Phycologia 35:148-155

Mackenzie L, Beuzenberg V, Holland P, McNabb P, Selwood A (2004) Solid phase adsorption toxin tracking (SPATT): a new monitoring tool that simulates the biotoxin contamination of filter feeding bivalves. Toxicon 44:901-918

- Maclean C, Cembella AD, Quilliam MA (2003) Effects of light, salinity and inorganic nitrogen on cell growth and spirolide production in the marine dinoflagellate Alexandrium ostenfeldii (Paulsen) Balech et Tangen. Bot Mar 46: 466-476

McGillicuddy DJ Jr, Anderson DM, Lynch DR, Townsend DW (2005) Mechanisms regulating large-scale seasonal fluctuations in Alexandrium fundyense populations in the Gulf of Maine: results from a physical-biological model. DeepSea Res II 52:2698-2714

McKinnon SL, Cembella AD, Quilliam MA, LeBlanc P and others (2004) The characterization of two new spirolides isolated from Danish strains of the toxigenic dinoflagellate 
Alexandrium ostenfeldii. In: Steidinger KA, Labdsberg JH, Tomas CR, Vargo GA (eds) Harmful Algae 2002. Florida Fish and Wildlife Conservation Commission, Florida Institute of Oceanography, and IOC of UNESCO, St. Petersburg, FL, http://research.myfwc.com/features/ view_article.asp?id=25973

Nascimento SM, Purdie DA, Lilly EL, Larsen J, Morris S (2005) Toxin profile, pigment composition, and large subunit rDNA phylogenetic analysis of an Alexandrium minutum (Dinophyceae) strain isolated from the Fleet Lagoon, United Kingdom. J Phycol 41:343-353

Ní Rathaille A (2007) Modelling Alexandrium bloom dynamics in Cork Harbour, Ireland. PhD dissertation, National University of Ireland, Galway

Ní Rathaille A, Touzet N, Raine R (2008) Inter-annual variability of Alexandrium blooms in Cork Harbour, Ireland. In: Moestrup $\varnothing$ et al. (eds) Proceedings of the 12th International Conference on Harmful Algae. International Society for the Study of Harmful Algae and IOC of UNESCO, 2008, Copenhagen, p 223-225

Ní Rathaille A, Touzet N, Raine R (2009) Factors controlling Alexandrium spp. bloom dynamics in Cork Harbour, Ireland. In: Busby P (ed) Proc 6th Int Conf on Molluscan Shellfish Safety, Blenheim, Marlborough, New Zealand, 18-23 March 2007. The Royal Society of New Zealand. Miscellaneous Series 71:49-54

Percy L, Morris S, Higman W, Stone D, Hardstaff WR, Quilliam MA, Lewis J (2004) Identification of Alexandrium ostenfeldii from the Fal Estuary, UK; morphology, molecular taxonomy and toxin composition. In: Programme and abstracts. XIth International Conference on Harmful Algal Blooms, Cape Town, South Africa

Probert IP (1999) Sexual reproduction and ecophysiology of the marine dinoflagellate Alexandrium minutum Halim. $\mathrm{PhD}$ dissertation, University of Westminster, London

Richard D, Arsenault E, Cembella A, Quilliam MA (2001) Investigations into the toxicology and pharmacology of spirolides, a novel group of shellfish toxins. In: Hallegreaff GM, Blackburn SI, Bolch CJS, Lewis RJ (eds) IXth International Conference on Harmful Algal Blooms. Intergovernmental Oceanographic Commission, Hobart, Australia, p 383-386

Editorial responsibility: Graham Savidge,

Portaferry, UK
Rundberget T, Gustad E, Samdal IA, Sandvik M, Miles CO (2009) A convenient and cost-effective method for monitoring marine algal toxins with passive samplers. Toxicon 53:543-550

Sogin ML (1990) Amplification of ribosomal RNA genes for molecular evolution studies. In: Innis MA, Gelfand DH, Sninsky JJ, White TJ (eds) PCR protocols. A guide to methods and applications. Academic Press, San Diego, CA, 307-314

Stobo LA, Lacaze JP, Scott AC, Gallacher S, Smith EA, Quilliam MA (2005) Liquid chromatography-mass spectrometry for analysis of lipophilic shellfish toxins described in EU Commission Decision 2002/225/EC. J AOAC Int 88: 1371-1382

Student (1908) The probable error of a mean. Biometrika 6: $1-25$

Touzet N, Franco JM, Raine R (2008a) Morphogenetic diversity and biotoxin composition of Alexandrium (Dinophyceae) in Irish coastal waters. Harmful Algae 7:782-797

Touzet N, Franco JM, Raine R (2008b) PSP toxin analysis and discrimination of the naturally co-occurring Alexandrium tamarense and A. minutum (Dinophyceae) in Cork Harbour, Ireland. Aquat Microb Ecol 51:285-299

- Touzet N, Keady E, Raine R, Maher M (2009) Evaluation of taxa-specific real-time PCR, whole-cell FISH and morphotaxonomy analyses for the detection and quantification of the toxic microalgae Alexandrium minutum (Dinophyceae), global clade ribotype. FEMS Microbiol Ecol 67: 329-341

Touzet N, Farrell H, Ní Rathaille A, Rodriguez P, Alfonso A, Botana LM, Raine R (2010) Dynamics of co-occurring Alexandrium minutum (Global Clade) and A. tamarense (West European) (Dinophyceae) during a summer bloom in Cork Harbour, Ireland (2006). Deep-Sea Res II 57: 268-278

Tukey JW (1949) Comparing individual means in the analysis of variance. Biometrics 5:99-114

Turrell E, Stobo L, Lacaze JP, Bresnan E, Gowland D (2007) Development of an 'early warning system' for harmful algal blooms using solid-phase adsorption toxin tracking (SPATT). In: Marine challenges: coastline to deep sea. Oceans '07, IEEE Aberdeen, Conference proceedings, Paper no. 070131-028

Utermöhl H (1958) Zur Vervollkommnung der quantitativen Phytoplankton-Methodik. Mitt Int Ver Limnol 9:1-38

Submitted: January 28, 2010; Accepted: December 6, 2010 Proofs received from author(s): February 25, 2011 